\title{
Thinking Essence, Thinking Technology: A Response to Don Ihde's Charge
}

\author{
Bowen Zha \\ Kyushu University, Faculty of Humanities, Fukuoka, JAPAN
}

Received: 6 April 2020 • Accepted: 25 May 2020 • Published Online: 2 June 2020

\begin{abstract}
Heidegger's seminal lecture, The Question Concerning Technology, has greatly influenced the contemporary philosophy of technology. However, scholars have different views regarding whether Heidegger's concept of technology is essentialist. On the one hand, Andrew Feenberg and Don Ihde have argued for this description, while on the other, Iain Thomson has claimed that, though Heidegger appears to be a technological essentialist, but does little to discredit his profound ontological understanding of the historical impact of technology. In this essay, I will focus on Ihde's critique and argue that his charge of essentialism is itself a misinterpretation of Heidegger's understanding of technology. I conclude that the meaning of essence in Heidegger's technology should be interpreted as that of "enduring," and in that way, describing Heidegger's concept of technology as essentialism is a metaphysical misinterpretation.
\end{abstract}

Keywords: Martin Heidegger, Don Ihde, the essence of technology, romanticism, essentialism.

\section{Introduction}

Martin Heidegger's 1953 lecture The Questions Concerning Technology remains one of the most influential textbooks in the philosophy of English technology. Although widely celebrated, Heidegger's dissertation is still regarded as an essentialist explanation of technology. Recently, technical philosophers such as Andrew Feenberg and Peter-Paul Verbeek reiterated this allegation of essentialism.

Many scholars have discussed Feenberg's critique of essentialism: those defending Heidegger, such as Iain Thomson, make the meaning of essentialism more patently clear (Thomson, 2000). Moreover, David Edward Tabachnick has defended varieties of essentialism from Feenberg's charge as an "aggressive" essentialism, a "moderate" essentialism and a "passive" essentialism (Tabachnick, 2007). However, the starting points of critiques as essentialism between Feenberg and Ihde are clearly different. As Robert C. Scharff pointed out, "Feenberg's primary concern is 'the social character of technology';" i.e., on one hand, for Feenberg, the charge of essentialism against Heidegger is not for seeking to clarify the nature of technology, but building the critique of scientism and its social, political, and economic consequences. On the other hand, Ihde's point of critique is "for socio-political issues mostly arise in reply to critics complaining about his 'descriptivism', a charge that typically prompts him to simply appeal to the 'normative implications' of his phenomenological descriptions" (Scharff, 2017). In this essay, my aim is to discuss Heidegger's view of technology within the context of Ihde's interpretations.

(C) Authors. Terms and conditions of Creative Commons Attribution 4.0 International (CC BY 4.0) apply. Correspondence: Bowen Zha (PhD student), Kyushu University, Faculty of Humanities, Philosophy Department, Fukuoka, JAPAN. E-mail: zhb.bowen.030@s.kyushu-u.ac.jp. 
In his lecture, Heidegger claims that a free relationship to technology is possible by questioning it and describes a technological phenomena as having an "essence" that does show modern technology itself at the level of what he terms "enframing": "The essence of modern technology shows itself in what we call enframing (Gestell)" (Heidegger, 2008: 328). For this point, in his major work Heidegger's Technologies: Postphenomenological Perspectives, Ihde emphasizes that Heidegger defined the essence of technology, which he calls a naïve and romantic prejudice, and should be criticized from three critical perspectives relating to Heidegger: historical, anti-romantic and pragmatically anti-essentialist. The premise of the anti-essentialist view is that "there are many varieties of technical experience," and therefore "one size does not fit all" (Ihde, 2010: 120). The historical angle of criticism focuses on Heidegger's famous judgment about science and technology, which is that although modern physical science begins earlier than machine-powered technology, "modern technology...is, from the point of view of essence holding sway within it, historically earlier" (Heidegger, 2008: 327). However, in this essay, considering that the target of Ihde's historical criticism is not only about the essence of technology but more focusing on the relations between the science and technology, here I would like to only focus on the latter two critiques which related to the meaning of essence.

My argument is structured in three sections. In the first section, to minimize potential objections, I will first interpret the criticisms Ihde put forward, including romantic criticisms and essentialist criticisms. In the second section, we will return to Heidegger's lecture and interpret Heidegger's understanding of the concept of essence. For grasping the essence of technology under the meaning of Heidegger's “essence", I suggest reconsidering Heidegger's thought on technology and the meaning of enframing, i.e. the essence of modern technology that makes modern technology endures. In the last section, I affirm that the two criticisms proposed by Ihde are born from a fundamental misunderstanding of the concept of the essence of technology. The key underpinning of his understanding of the meaning of technology is found not in Heidegger's own words, but rather springs from a traditional metaphysical understanding. These conclusions help justify Heidegger's innovative approach to understanding technology.

\section{Romanticism criticism and anti-essentialism criticism}

As mentioned earlier, in Heidegger's Technologies, Ihde explicitly opposed Heidegger's view of describing the essence of modern technology as enframing. However, this is not sufficient for our purposes, because it cannot tell us why essentialism is inadequate. We need to step nearer to evaluate Ihde's critiques.

Ihde insists that "there is no essence of technology, although there are many 'technologies"' (Ihde, 2010: 119); therefore, all essentialist theories of technology are untenable because it is not possible to try to summarize all technologies into one particular essence with certain properties. Based on this view, Ihde gives his propositions: romantic criticism and pragmatist-antiessential criticism. Our next task will be to unravel these two propositions in order to understand why the essence of technology is unreliable. Then we will return to each claim in turn and ask Heidegger if he holds any objectionable doctrine.

\subsection{Deromanticizing Heidegger}

According to Ihde, some of Heidegger's technological theories stem from nostalgic, mysterious romanticism. Heidegger has evidenced obvious preferences for specific technical products (including artwork), praising water-driven mills, ancient Greek temples, and ancient stone bridges, while belittling the nearby hydroelectric power stations on the Rhine and modern viaducts. From these examples, it seems that Heidegger's view of technology related to "a certain suspicion concerning modern technology versus traditional technologies, and the older, smaller 
and simpler technologies versus the newer, larger, and more complex technologies" (Ihde, 2010: 76).

However, Ihde found that there is no qualitative difference in the use of natural power as a resource between water-driven mills and hydropower stations. Additionally, according to the research by J. Donald Huges, Ihde points out that the glorious ancient Greek temple reveals a very different "world" from that of Heidegger, which was originally set against the bare dry mountains (Ihde, 2010: 75) Therefore, despite the romantic and poetic imagery, these examples taken by Heidegger cannot be considered an historical and ecological view. Ihde thus pointed out that it should be clear that the romantic thesis pervades Heidegger's choices of "good" and "bad" technologies and there are two elements for Heidegger's romanticism preferences.

The first preference Heidegger follows is the principle of "embodiment relations." "Heidegger prefers, likes, those technologies that express straightforward bodily, perceptual relations with the environment" (Ihde, 2010: 78). By analyzing examples of pens and typewriters, for example, Ihde points out that the reason Heidegger disparages the typewriter is because the pen better blends with the hand to convey a variety of personality, whereas the monotonous mechanics of the typewriter do not. The origin of this principle can be traced back to Heidegger's preference for simple tools such as hammers in his very famous analysis in Being and Time. Through the example of children's obsession with a spinning top, Ihde claims that we can find an "alterity relations", on which "to relate to a technology in a positive way and in a situation in which the artifact takes" (Ihde, 2010: 79) Therefore, the preference for embodiment relations is a deep reason for Heidegger's romantic expression of primitive technological products.

The second element of Heidegger's preferences is his love of art/poetry and deprecation of technology. In his eyes, art is an authentic and famous expression that gathers "the sky, earth gods and mortals" (Himmel, Erde, Götter und Sterbliche) as the Fourfold (Geviert); in contrast, the modern technology that enframes nature is inauthentic, and this very inauthentic closure places people in danger. But Ihde claims that authenticity is just a romanticized representation of Heidegger's, which could even be used to beautify something as potentially dangerous as nuclear power plants (Ihde, 2010: 82). The dangerous nuclear power plants can be as "authentic" as a Greek temple under a romantic description. As a result, romanticized expressions are often divorced from reality, obscuring the political implications of real-world technology products:

By adding this politics of our artifacts to the analysis...the account becomes even more powerful. What needs to be noted, however, is that the romantic thesis in its unsaying concealment has all along hidden this politics of the thingly. It hid the Greek politics of the thingly just as well as it hides ours. (Ihde, 2010: 83)

By deromanticizing Heidegger, Ihde shows that returning to ancient times is not the way to solve modern technical problems. There were also ecological/environmental problems caused by the application of technology when building the temple in ancient Greek. His deromanticization also acts to remove the prejudice towards modern technology, and the application of technology in the life-world should be analyzed and evaluated thoroughly from a phenomenological perspective. Therefore, romanticism's rejection against modern technology is an anachronistic Lutheranism.

We will hold off on evaluating this objection of Ihde's and asking whether it really applies to Heidegger until the other objection is on the table.

\subsection{Anti-essentialism: One size cannot fit all}

Let us turn, then, to anti-essentialism. Ihde clarifies: "I claim that technologies are multistable, that is, they have structured ambiguities that allow what first appears as a 'same' 
technology to be differently situated and have different trajectories" (Ihde, 2010: 126).

Furthermore, by analyzing the example of the multidimensionality of the Necker cube, Peter-Paul Verbeek summarizes Ihde's concept of multistabile aspects on one cube to clarify that "what it 'really' remains undetermined. It is many things at once; it is 'stable' in multiple ways" and he comes to the conclusion that technologies are "only technologies in their concrete use, and this means that one and the same artifact can have different identities in different use contexts" (Peter-Paul Verbeek, 2005: 118)

Ihde acknowledges that Heidegger's argument on technology is correct and profound at some points, but does one enframing apply to all technologies? Apparently not. Ihde's antiessentialist critique of Heidegger begins with the typewriter again, a mechanized writing technique. Ihde claims that there are two reasons Heidegger hates to write on typewriters: typewriters produced seemingly identical text, which is a covering up one's handwriting and therewith one's character. In mechanized writing, all human beings look the same, whereas handwriting is the complete preservation of one's personality. Second, typewriters produce text that is "typed" by the hand with a simple press, while the handwritten text "flows" from the human mind. Compared with typewriters, the pen can be better integrated with the hand to express the thought more smoothly.

The mechanical construction technology of a typewriter is mainly embodied in the mechanical device of keyboard. Therefore, the empirical investigation of Ihde's postphenomenology is firstly carried out around the evolution of the technology of keyboard, but the function field is transferred from the typewriter keyboard to the musical instrument keyboard.

In the 19th century, key instruments began to appear in large numbers in Europe. The clarinet was equal to the flute and the keyboard, and the piano was equal to the harp and the keyboard. Keyboard is easy for players to operate, can produce more accurate and clear music, so that faster playing skills are possible. But these changes also attracted much criticism: the use of finger placement to produce vibrato was lost, and as well as control over finger positions to correct out of tune sounds. These complaints are similar to Heidegger's reasons for disregarding the typewriter. However, the appearance and use of the piano obviously did not make the performance of the same music completely uniform, and the distinction between a trained pianist and a beginner is still obvious (Ihde, 2010: 122f).

Second, whether the words "flow" from thought or are "typed" mechanically on the keyboard depends on proficiency in the use of writing instruments. However, there is an inexperienced process of learning and adaptation before any tool is used proficiently, therefore the "withdrawal" phenomenon of tools in ready-to-hand cannot summarize the characteristics of all tool being used. Based on the famous concepts of ready-to-hand and presence-at-hand, Ihde cites:

Any new technology in relation to human praxis, before it can become transparent and thus fully accommodated, must be "embodied" if it is to be "known" at all. In short, something like presence-at-hand, although in phenomenologically different ways, lies at both beginnings and breakages. (Ihde, 2010: 124f)

Idhe uses the period of inexperience when faced with new tools to point out that even handwriting requires an phase of unfamiliarity, as we learning how to write letters with pen and our hand, and that proficiency with the typewriter produced the effect of ideas "flowing" through the typewriter into the text; furthermore, the skillful use of the typewriter can also produce a "flow" of thought from the thought to the text.

Therefore, through a postphenomenological revelation of different writing experiences, Ihde shows that Heidegger's technological analysis is highly amusing and phenomenologically arbitrary. The clarifying of the essence of technology must be a kind of 
metaphysics, essentialism that reduces all different technologies to one essence. In this case, Ihde points out from a historical and empirical view that there are actually many variations of technical experience, and thus makes his statement that "one size cannot fit all." Returning to the typewriter as an example, Ihde further points out that the phenomenological change of technical experience should have a macro and historical dimension in addition to the micro-level of body perception. In the history of the development of human technology, different periods have used different writing technologies. Ranging from ancient techniques such as the first symbols on turtle shell, cuneiform, ancient Chinese calligraphy, and Egyptian hieroglyphics on papyrus, to a pen, the typewriter, and word processing software, those human-writing technologies "display different patterns of selectivity, of amplification and reduction, such that not everything can be expressed as well or at all, in each variant" (Ihde, 2010: 134).

Ihde's criticism of Heidegger can thus be summarized in the following two points: (1) Heidegger's view on technology focuses on embodiment relation and ready-to-hand technology, specifically in traditional technology such as the hammer. He has a romantic tendency and prefers technologies with classical elements, such as Greek temples. (2) The diverse background of technology indicates that technology itself cannot be reduced to a single essence; not everything can be expressed as well or at all in each variant.

\section{Heidegger on the essence of technology}

What exactly is Heidegger's understanding of the essence of technology? Heidegger's most famous claim, that the essence of technology is nothing technological, may not initially seem to be of much help. Let us turn to the meaning of "essence" first. In the broadest terms, essentialism implies that things have an "essence". Rather than being artificial, all objects or beings, whether rocks, clouds, horses or people, have a quality, character or nature intrinsic to their being which could distinguish them from other things. Aristotle explains, "the essence of a thing is what it is said to be in respect of itself" (Metaphysics, 1029b14).

However, Heidegger's understanding of "essence" differs from the traditional definition. Traditionally, this concept has two meanings: the first is the "What" (Was, quidditas and essentia) something is. The second meaning refers to the genus (Gattung) of the thing, that is, the universal which encompasses all actual and possible versions of that thing (Heidegger, 2008: 334) In terms of the essence of the tree, for example, according to two traditional meanings, it implies both the sameness of Treeness (Baumhafte) attributed to trees of all kinds and the genus that contains all actual and possible trees. The two essential concepts mentioned above, that is, the stipulation of content or universal beings, are actually at the ontic level.

However, "essence" here is not defined with genus and essentia. Heidegger says that when we speak of the "essence of a house" and the "essence of a state" we do not mean a generic type, "rather we mean the ways in which house and state hold sway, administer themselves, develop and decay" (Heidegger, 2008: 335), thus in a more original ontological meaning, "enduring". The reason why it is called "more original ontological meaning" is that what Heidegger wants to trace is what makes the concept of essence on a metaphysical and ontic level possible, and thus that is more qualified to be called the original concept of essence.

Only by this meaning, the essence as the universal being is fundamentally based on the abstraction of the enduring beings. That is to say, it is only by being enduring that can something be abstracted from its "whatness" or genus, and thus the essence in the sense of universal is possible, and the universal being in the sense of genus is possible.

But this is only the first step. Actually, Heidegger already notices that "Socrates and Plato already think the essence of something as what it is that unfolds essentially, in the sense of what endures." However, his dilemma is that "it can never in any way be established that enduring 
is based solely on... what metaphysics in its most varied interpretations thinks as essentia" (Heidegger, 2008: 335f) Therefore, since essence is traced back to enduring beings, Heidegger questions further about the conditions that make the ontic essence possible.

For something being possible to endure, as a premise, it needs to get to become their own constantly endures to be presence. Only in the enduring, can enduring beings become themselves so that can be understood as the essence in the meaning of metaphysics by us. Thus, in this space before something becomes itself, enduring must be considered as a possible condition for beings enduring. In this way, essence cannot be conceived as the unchanging state of what remains of the continuant, but must be grasped as the continuous formation that makes the continuant possible.

For example, when we describe someone as a good or a bad person, we often judge whether the person's essence (whatness) is good or bad by thinking about the person's usual behavior, which is in the general metaphysical way. But what Heidegger is trying to ask is, "what are the conditions that make this person endure him/herself?" i.e., to consistently do good or bad things. This factor is the essence that determines whether the person is good or bad. For without this decisive factor, the element of the person continuing to do something good or bad disappears, and we cannot grasp his essence. It is difficult to define the essence of a murderer who, for argument's sake, would also sacrifice himself on behalf of all humankind to save the planet as good or bad.

Heidegger's attribution of the concept of essence to enduring has an etymological basis. It is from the verb "essence" (wesen) that the noun essence (Wesen) is derived, and the verb wesen is the same as währen (to last or endure). As mentioned above, Heidegger takes "essence of a house"(Hauswesen) and "essence of a state" (Staatswesen) to point out that actually we mean "the ways in which house and state hold sway, administer themselves, develop, and decay - the way they essentially unfold (wesen)" (Heidegger, 2008: 335). Furthermore, as Heidegger quoted that, Hebel uses die Weserei, city hall, in his poem, "inasmuch as there the life of the community gathers and village existence is constantly in play" (Ibid.). In other words, as an example of this enduring meaning, the community will endur to thrive only if the city hall endures to thrive and flourish.

Therefore, in Heidegger's view, the original essence is enduring. That is to say, as the dominant force, it ultimately determines the character of beings, which is, what it is; and also determines the universal being, that is, the beings in the "genus".

Thus, different from the traditional essence concept of genus and universal being, essence for Heidegger is the transcendentalization of traditional essential concepts. What Heidegger is concerned about is in what meaning and with what conditions the meaning of metaphysical essence could become possible. Because the concept of essence in this original sense is the premise for the possibility of the concept of essence in the traditional meaning, it is qualified to be called the real "essence".

\section{Thinking essence, thinking technology}

With this interpretation of essence in mind, let us now evaluate Ihde's objections.

\subsection{Romanticism?}

Ihde points out that Heidegger's romanticism takes two basic forms, "embodiment relations" and a tendency to favor the artistic and traditional. However, when we combine the two criticisms of Ihde, it seems that there is an irreconcilable contradiction in his claim of Heidegger's romanticism.

A simple example is that of the Greek temples that are so praised in Heidegger's work. 
There is no indication of the embodiment relationship that defines the other, ancient or simple modes of technology that are valued over modern ones. Furthermore, considering the structure and structure of the ancient Greek temples, even in the present day, the difficulty and complexity of the structure cannot be considered "simple". "Greek architecture does not amaze and overwhelm with mere scale and complexity; it has vigor, harmony, and refinement that thrill the mind as well as the eye" (Trachtenberg, 2003: 91).

Secondly, Ihde seems to imply that Heidegger has a deep ecological orientation, that is, his preferences are for those technologies that do not negatively affect the environment. However, the Greek temple example does not lead to an eco-friendly conclusion, because the reason Heidegger considers the Greek temple as a good example is not that the temple did not cause environmental destruction, but rather that it encompasses the meaning of essence in which Greek values were preserved and thus enduring, that is "the temple held up to the Greeks what was important, and so let there be meaningful differences such as victory and disgrace, disaster and blessing" (Dreyfus, 2006: 353).

Heidegger, to say the least, did not pay much attention to environmental preservation as we would consider it as in modern times, but was more concerned about a more technically danger caused by framing nature which would prevent us from the various understandings and revealings of the being. For Heidegger, the danger is not "the destruction of nature or culture but certain totalizing kinds of practices - a leveling of our understanding of being" (Dreyfus, 2006: $361)$.

Here, there is an incredible difference in the thought on technology between Ihde and Heidegger. By analyzing all kinds of practical technology forms, what Ihde wants to reveal is a phenomenological description of technology products, and through the phenomenological view, the way how products of technology reveal their beingness in an ontic way. And on this point, I have to admit that it is impossible to grasp the essence of technology if this essence is drawn from various, disparate technologies.

However, if Ihde starts from this perspective, there is a major flaw in his empirical theory when he criticizes Heidegger. When Ihde pointed out what he thought was deficient in Heidegger's theory of technology, that is, when he claimed that in Heidegger's technology, it "appear(s) that the two most frequently patterned such differences relate to a certain suspicion concerning modern technology versus traditional technologies, and the older, smaller and simpler technologies versus the newer, larger, and more complex technologies" (Ihde, 2010: 76), how did he himself define "traditional" and "modern" technology from the perspective of technological development?

In other words, if Ihde criticizes Heidegger from the empirical perspective of a variety of technical products for Heidegger's tendency to favor traditional technology, Ihde himself lacks a standard for distinguishing traditional technology from Modern technology. Therefore, I claim that it is impossible to make this discernment between traditional and modern technology using empirical and historical perspectives.

As Ihde himself points out, the ancient waterwheel was no different from the hydroelectric power station on the Rhine. So again, if we for example think of the invention and use of the steam engine as a watershed between tradition and modernity, how can we tell the difference between the technology that was used in the decade before the invention of the steam engine and the technology that was used in the decade after the invention of the steam engine? The development of technology is continuous, and the argument against the criticism of Heidegger from the empirical perspective is itself untenable. It is a continuum fallacy.

So, we can say that Ihde's critique of Heidegger's romanticism is essentially a strawman based on a misunderstanding and misinterpretation of Heidegger's use of "essence". Heidegger's 
concern with the technology problem is not trying to form all kinds of technologies itself, but the phenomena that how would the enframing endure and what makes it possible, and the essence underlying and causing enframing which he called Metaphysic.

Let us turn to one of Ihde's more telling objections, his claim that Heidegger's understanding of technology is one size fits all.

\subsection{One size "fits" all?}

Ihde claims that the diverse background of technology indicates that technology itself has been reduced to a single essence, hence his conclusion that one size cannot fit all. But this stems from a traditional understanding of essence, which is the essence as genue. Meanwhile what Heidegger asks is not "the essence of technology...that Heidegger is not seeking a definition. His question cannot be answered by defining our concept of technology" (Dreyfus, 2006: 361), but the essence that makes modern technology enduring in the way that all beings are considered a resource.

Let's return to the thought of Heidegger. First, Heidegger is not opposed to the use of modern technology, nor is he a Luddierism. He sees that "it would be foolish to attack technology blindly. It would be shortsighted to condemn it as the work of the devil. We depend on technical devices; they even challenge us to ever greater advances" (Heidegger, 1975: 53). Secondly, what Heidegger criticizes is not modern technology itself, but the essence and the phenomena causes and endures it - that is, a metaphysical way of thinking: "We pursue the development of our potential simply for the sake of further growth. We have no specific goals" (Dreyfus, 2006: 362).

The difference between Heidegger's concept of technology and Ihde's is that Heidegger is always at the understanding and revealing of being, that is, the primitive state of beings, to consider how beings become themselves (Seinlassen), thus criticizing modern technology. Of course, there's no denying that Heidegger also noticed that "the same artifact can have different identities in different use contexts" (Peter-Paul Verbeek, 2005: 118).

In the activities of modern society, our human activities are no different from those of ancient Greece. But Heidegger notices that the "essence" of our activities has changed:

The forester who measures the felled timber in the woods and who to all appearances walks the forest path in the same way his grandfather did is today ordered by the industry that produces commercial woods, whether he knows it or not. (Heidegger, 2008: 323)

This example of the forester shows that, in the same technological activities when contexts have changed, although the technological form is the same, the meanings have changed. This is an excellent example of what Ihde calls the technical context for defining technology. But what Heidegger sees is not just the various ontic forms, but is the changing of foundational essences for human because of the enframed by modern technology.

\section{Conclusion}

Heidegger's critique is not a critique of the product of technologies, but of the force that makes modern technology activities endure - the enframing. Enframing is not the essence of modern technology in the ontic and metaphysical meaning, but in the ontological, which enables modern technology to continue to endure. Ihde, on the other hand, does not see the meaning of essence as that which makes beings endure, so his critique of Heidegger is thus reduced to a fundamentally erroneous. 


\section{Acknowledgements}

This research did not receive any specific grant from funding agencies in the public commercial, or not-for-profit sectors.

The author declares no competing interests.

The author would like to express his very great appreciation to Lilly Gray for her valuable and constructive suggestions on editing of this research work. Her willingness to give her time so generously has been very much appreciated.

\section{References}

Dreyfus, H. L. (2006). Heidegger on the connection between nihilism, art, technology, and politics. In C. B. Guignon (Ed.), The Cambridge companion to Heidegger (pp. 345-372). Cambridge University Press.

Heidegger, M. (1975). Discourse on thinking. New York: Harper \& Row.

Heidegger, M. (2008). Basic writing. Harper.

Ihde, D. (2010). Heidegger's technologies: Postphenomenological perspectives. Fordham University Press.

Peter-Paul Verbeek, T. R. (2005). What things do: Philosophical reflections on technology, agency, and design. The Pennsylvania State University Press University Park, Pennsylvania.

Scharff, R. C. (2017). On living with technology through renunciation and releasement. Foundations of Science volume 22, 255-260.

Tabachnick, D. E. (2007). Heidegger's essentialist responses to the challenge of technology. Canadian Journal of Political Science, 487-505.

Thomson, I. (2000). What's wrong with being a technological essentialist? A response to Feenberg. Inquiry, 429-44.

Trachtenberg, M. (2003). Architecture: From prehistory to postmodernity. Pearson. 
B. Zha - Thinking Essence, Thinking Technology: A Response to Don Ihde's Charge

C O A $\mathbf{s}$ 